\title{
Leopard (Panthera pardus) predation on a red-tailed monkey (Cercopithecus ascanius) in the Issa Valley, western Tanzania
}

\author{
Edward McLester $^{1}\left(\mathbb{D} \cdot\right.$ Kyle Sweeney $^{2} \cdot$ Fiona A. Stewart $^{1,2} \cdot$ Alex K. Piel $^{1,2}$
}

Received: 10 July 2018 / Accepted: 11 November 2018 / Published online: 17 November 2018

(c) The Author(s) 2018

\begin{abstract}
Predation is predicted to be an important selection pressure for primates. Evidence for this hypothesis is rare, however, due to the scarcity of direct observations of primate predation. We describe an observation of leopard (Panthera pardus) predation on a red-tailed monkey (Cercopithecus ascanius schmidti) at the Issa Valley, a savanna-woodland mosaic landscape in western Tanzania. We compare rates of evidence of leopard presence between Issa and other primate study sites in sub-Saharan Africa. An increase in direct observations of leopards at Issa in recent years suggests that leopards may be habituating to researcher presence.
\end{abstract}

Keywords Guenon $\cdot$ Savanna-woodland mosaic $\cdot$ Predator habituation $\cdot$ Anti-predator behavior

\section{Introduction}

Predation is predicted to be a critical selection pressure in primate evolution (Anderson 1986; Treves 1999; Zuberbühler and Jenny 2002). For example, predator avoidance is a primary explanation for the evolution of group living —an otherwise disadvantageous strategy given increased rates of intra-group feeding and mate competition (Isbell 1991; Majolo et al. 2008). Group-living primates benefit from increased collective vigilance, better defence against predators (e.g. mobbing), and greater dilution of risk among group members (Morse 1977; Boinski et al. 2000; Treves 2000). Despite this, larger groups are more conspicuous and more likely to be detected by predators (Boinski et al. 2000). While the evolutionary significance of predation is therefore of interest, testing the extent of predation as a selective pressure is difficult due to the rarity of direct observations of predation events.

Multiple factors likely influence primate vulnerability to predation. Habitat structure should determine optimal opportunities for predators as well as prey vulnerability

Edward McLester

e.mclester@2016.ljmu.ac.uk

1 School of Natural Sciences and Psychology, Liverpool John Moores University, Byrom Street, Liverpool L33AF, UK

2 Greater Mahale Ecosystem Research and Conservation Project, Box 60118, Dar es Salaam, Tanzania
(Isbell 1994). For example, harpy eagles (Harpia harpyja) may preferentially hunt primates in clearings or open canopy forest (Eason 1989), and chacma baboons (Papio ursinus) avoid vegetation types that are associated with higher predation risk (Cowlishaw 1997). The diversity and densities of predators should also affect encounter and predation rates (Anderson 1986). As such, for primates in open habitats (e.g. savanna-woodland mosaics) predation pressures may differ compared to closed canopy, densely vegetated habitats (e.g. tropical forests; Crook and Gartlan 1966; Anderson 1986; Dunbar 1988; Cords 1990; Isbell 1994). The diversity of potential primate predators also varies between open and closed environments, with open habitats hosting species that are no longer found or have never been historically present in tropical forests (e.g. African wild dogs, Lycaon pictus; spotted hyenas, Crocuta crocuta-Baldwin et al. 1981; Stewart and Pruetz 2013).

We describe an incident of predation on a red-tailed monkey (Cercopithecus ascanius schmidti), a species that typically inhabits primary and secondary forests, as well as open habitats (Sarmiento et al. 2001). Specifically, we observed a leopard (Panthera pardus) that preyed upon on a single monkey at the Issa Valley, a savanna-woodland mosaic landscape in western Tanzania. 


\section{Methods}

The Issa Valley study site is located approximately $90 \mathrm{~km}$ inland of Lake Tanganyika and equidistant between Gombe and Mahale Mountains National Parks. Research at Issa focuses on an approximately $60 \mathrm{~km}^{2}$ area of steep valleys and flat plateaus at an elevation of 1150-1712 m. The site has no formal protection status. The nearest settlement to the site (Mishamo) is $20 \mathrm{~km}$ away. Human presence in the study area occurs, primarily due to illegal poaching, logging, and cattle herding in the peripheries of the site (Piel et al. 2015). Climate is characterized by two distinct seasons: a wet season during November-April and an extended dry season $(<100 \mathrm{~mm}$ total monthly rainfall) during May-October (Hernandez-Aguilar 2009). Mean total annual rainfall was $1012 \mathrm{~mm}$ (range 760-11276 mm) in 2013-2015 (unpublished data). Vegetation is a savannamosaic, consisting primarily of miombo woodland dominated by Brachystegia and Julbernardia spp. with a savanna grass understory (Piel et al. 2017). Remaining vegetation is made up of a small proportion ( $4 \%$ cover) of evergreen and semi-deciduous gallery forest found in thin strips, as well as swamps and open grasslands. Canopy cover is mostly closed in gallery forest, and mostly open in woodland.

Red-tailed monkeys at Issa have been habituated since 2012. In 2018, two study groups (K1 and K2) were followed by two-person research teams for 5-10 days per alternate month. At the time of this study, $\mathrm{K} 1$ group numbered approximately 30 individuals and $\mathrm{K} 2$ group numbered 10 individuals. A single adult male was present in each group. To our knowledge, this is the only long-term study of red-tailed monkeys in a savanna-mosaic habitat.

Possible predators of red-tailed monkeys at Issa include five large carnivores: leopards, lions (P. leo), African wild dogs, East Africa black-backed jackal (Canis mesomelas schmidti), and spotted hyenas. Although these species are infrequently seen, African wild dogs have previously been observed to investigate a chimpanzee (McLester et al. 2016) and all five species are considered capable of preying on primates (Iwamoto et al. 1996; Stewart and Pruetz 2013). At least one species of raptor present at Issa that is known to prey upon red-tailed monkeys is the crowned hawk-eagle (Stephanoaetus coronatus-Skorupa 1989; Struhsaker and Leakey 1990; Mitani et al. 2001). Other likely prey for carnivores and raptors at Issa include duikers (Philantomba and Sylvicapra spp.), hyraxes (Heterohyrax and Dendrohyrax spp.), cane and giant pouched rats (Thryonomys and Cricetomys spp.), hares (Lepus spp.), bushbuck (Tragelaphus scriptus), Lichtenstein's hartebeest (Alcelaphus lichtensteinii) and antelopes (Hippotragus spp.; Stewart 2011). Chimpanzees are also sympatric with red-tailed monkeys at Issa, and although they have never been observed to prey upon monkeys at this site, they are known to consume a range of other animals (e.g. blue duiker, P. monticola; bush pig, Potamochoerus porcus; cane rat-Ramirez-Amaya et al. 2016; unpublished data). Potential snake predators of red-tailed monkeys at Issa include African rock pythons (Python sebae), black mambas (Dendroaspis polylepis), black-necked spitting cobras (Naja nigricollis), and puff adders (Bitis arietans), as per observations of predation involving cercopithecine species from other sites (e.g. Isbell 1990; Barrett et al. 2004; Isbell 2006; Foerster 2008).

\section{Observation}

On 10 March 2018, KS and a field assistant MM followed K1 group from 07:00. At around 18:00, the group travelled along a strip of gallery forest adjacent on either side to miombo woodland. The width of the strip varied between 40 and $120 \mathrm{~m}$. Forest canopy height at this location was approximately $20-25 \mathrm{~m}$ over the river and 5-15 m bordering the woodland. Woodland vegetation consisted of thin trees with canopy height of approximately $10 \mathrm{~m}$ and vegetation on the ground was comprised of short $(<1 \mathrm{~m})$ grass, moss, and bushes. Horizontal group spread (greatest distance between two individuals) was at least $50 \mathrm{~m}$, with a majority of the group located in forest and a small number of individuals located in the woodland. The group was not associating with any other species. All of the monkeys in sight of the researchers were arboreal and positioned between 5 and $10 \mathrm{~m}$ high.

At 18:04, KS and MM were following different focal monkeys to the prey individual and were positioned approximately 50 and $30 \mathrm{~m}$ from the location of the interaction, respectively. MM observed a single, small- to medium-sized leopard approach the group terrestrially and slowly through the woodland, using a tree trunk for cover at one point. MM first observed the leopard when it was approximately $20 \mathrm{~m}$ from the group and at one point observed that the leopard appeared to look directly at her. MM was not able to identify the age or sex of the leopard. Approximately 8-10 m from the prey, the leopard continued rapidly through the woodland, climbed a vertical trunk, and seized the individual approximately $4 \mathrm{~m}$ above ground in a 5-10 $\mathrm{m} \mathrm{Mon-}$ opetalanthus richardsiae tree, and carried the monkey back through the woodland into the forest. The researchers were not able to identify the age-sex class of the prey. The closest neighboring monkey was approximately $1 \mathrm{~m}$ away from the victim at the time of the attack. The prey individual was located on the relative edge of the group but was not the most peripheral individual-i.e. other members of the group were located around the individual in horizontal space. The 


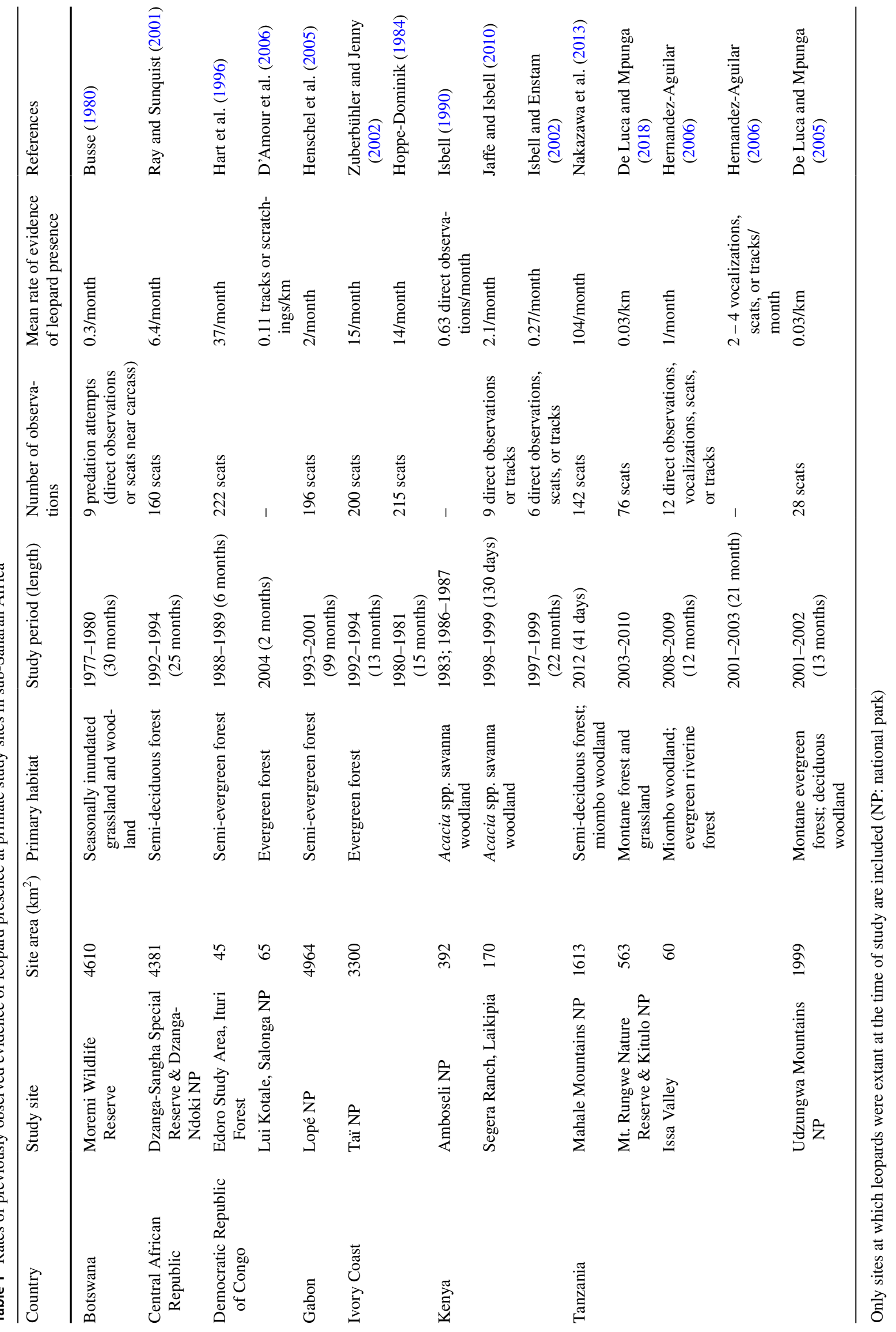


tree in which the prey individual was attacked was located in woodland approximately $10 \mathrm{~m}$ away from the forest. Local canopy cover was sufficient for monkeys to move between trees without travelling terrestrially. The researchers identified scratches in the bark up to $1.7 \mathrm{~m}$ high that were likely to have been left by the leopard's claws.

In response to the attack, the adult male and numerous females and juveniles climbed higher into the canopy. The male produced ka-train or "hack" alarm calls, and numerous females and juveniles produced ka-trains and chirps (Cords and Sarmiento 2013). The researchers did not observe any monkeys mobbing the leopard. All alarm vocalizations had subsided by 18:25. The group continued to travel primarily within and following the forest strip in the same direction as prior to the interaction. By 18:30, the researchers observed members of the group foraging arboreally within $5 \mathrm{~m}$ of the ground.

The location of the interaction was in the approximate core of $\mathrm{K} 1$ group's range at the intersection of three major valleys and where the monkeys frequently travel in order to access different valleys (unpublished data). K1 group visited this location at most 18 days prior to the attack during six consecutive follow days conducted the previous month. The group next travelled through this location 2-8 days later.

\section{Discussion}

This encounter is the first direct observation of leopard predation on a red-tailed monkey at the Issa Valley, despite over $2800 \mathrm{~h}$ of focal follows since January 2013. Evidence of leopard presence is observed consistently at Issa, although less frequently than at primarily forested sites (Table 1). For example, Hernandez-Aguilar (2009) and Stewart and Pruetz (2013) observed evidence once per 2 weeks and once per month, respectively, during two of the first studies to be conducted at Issa (see also Russak 2014). In recent years, direct observations of leopards have become more common. Researchers encountered leopards eight times in 2015, compared with two observations made in 2012-2014 (unpublished data). Although anecdotal, a range of leopard responses to researchers have been observed including fleeing, staying and watching researchers, and growling (EM personal observation; as per Sweanor et al. 2005). That the leopard in this observation appeared to detect one researcher and still continued the attack could suggest that leopard habituation to researcher presence is increasing at Issa.

We did not observe the red-tailed monkey preyed upon to exhibit the greatest predation risk predicted by hypotheses of anti-predator behavior. For example, to maximize the chances of successful predation, predators should target the single most vulnerable animal in a group (Hamilton 1971). Frequently, this individual is isolated or on the periphery of the group (e.g. Quinn and Cresswell 2006; Josephs et al. 2016). In our observation however, the prey individual was neither isolated nor the most peripheral individual. It is possible that while the prey individual was less exposed than the most peripheral individual, it was also less vigilant and therefore more easily targeted by the leopard. Similarly, the leopard also attacked an individual from the larger of the two study groups, which does not support the hypothesis that smaller groups are more vulnerable to predation than larger groups (Janson and Goldsmith 1995; Stanford 1995). More data are needed to investigate whether open habitat-dwelling primates exhibit habitat-specific anti-predator behavior compared to primates in closed habitats.

Author contributions EM, KS, FS, and AP wrote the manuscript; KS and EM collected data; AP and FS acquired primary funding and direct all research activities at Issa. We thank the Tanzanian Wildlife Research Institute (TAWIRI) and the Commission for Science and Technology (COSTECH) for permission to conduct research at the Issa Valley. We thank the UCSD/Salk Center for Academic Research and Training in Anthropogeny (CARTA) for support for the GMERC Project. EM's fieldwork was funded by the American Society of Primatologists and Liverpool John Moores University. We thank Mariana Marco and Allison Rogers for helping to record details and Lily Fornof for cleaning ranging data.

Open Access This article is distributed under the terms of the Creative Commons Attribution 4.0 International License (http://creativeco mmons.org/licenses/by/4.0/), which permits unrestricted use, distribution, and reproduction in any medium, provided you give appropriate credit to the original author(s) and the source, provide a link to the Creative Commons license, and indicate if changes were made.

\section{References}

Anderson CM (1986) Predation and primate evolution. Primates 27:15-39

Baldwin PJ, Pí JS, McGrew WC, Tutin CEG (1981) Comparisons of nests made by different populations of chimpanzees (Pan troglodytes). Primates 22:474-486. https://doi.org/10.1007/bf02381239

Barrett L, Gaynor D, Rendall D, Mitchell D, Henzi SP (2004) Habitual cave use and thermoregulation in chacma baboons (Papio hamadryas ursinus). J Hum Evol 46:215-222. https://doi.org/10.1016/j. jhevol.2003.11.005

Boinski S, Treves A, Chapman CA (2000) A critical evaluation of the influence of predators on primates: Effects on group travel. In: Boinski S, Garber PA (eds) On the move: how and why animals travel in groups. The University of Chicago Press, Chicago, pp $43-72$

Busse C (1980) Leopard and lion predation upon chacma baboons living in the Moremi Wildlife Reserve. Botsw Notes Rec 12:15-21

Cords M (1990) Vigilance and mixed-species association of some East African forest monkeys. Behav Ecol Sociobiol 26:297

Cords M, Sarmiento EE (2013) Red-tailed monkey Cercopithecus ascanius. In: Butynski TM, Kingdon J, Kalina J (eds) Mammals of Africa, Primates, vol 2. Bloomsbury, London, pp 375-381

Cowlishaw G (1997) Trade-offs between foraging and predation risk determine habitat use in a desert baboon population. Anim Behav 53:667-686 
Crook JH, Gartlan JS (1966) Evolution of primate societies. Naturw 210:1200-1203

D'Amour DE, Hohmann G, Fruth B (2006) Evidence of leopard predation on bonobos (Pan paniscus). Folia Primatol 77:212-217. https ://doi.org/10.1159/000091230

De Luca DW, Mpunga NE (2005) Carnivores of the Udzungwa mountains: presence, distributions and threats. Wildlife Conservation Society, Mbeya, p 38

De Luca DW, Mpunga NE (2018) Leopard abundance, distribution and food habits in the Mt. Rungwe-Kitulo landscape, Southern Tanzania. Afr J Ecol 56:358-367. https://doi.org/10.1111/aje.12464

Dunbar RIM (1988) Primate social systems. Croom Helm, London

Eason P (1989) Harpy eagle attempts predation on adult howler monkey. The Condor 91:469-470

Foerster S (2008) Two incidents of venomous snakebite on juvenile blue and Sykes monkeys (Cercopithecus mitis stuhlmanni and $C$. m. albogularis). Primates 49:300-303. https://doi.org/10.1007/ s10329-008-0098-x

Hamilton WD (1971) Geometry for the selfish herd. J Theor Biol 31:295-311

Hart JA, Katembo M, Punga K (1996) Diet, prey selection and ecological relations of leopard and golden cat in the Ituri Forest, Zaire. Afr J Ecol 34:364-379

Henschel P, Abernethy KA, White LJT (2005) Leopard food habits in the Lopé National Park, Gabon, Central Africa. Afr J Ecol 43:21-28

Hernandez-Aguilar RA (2006) Ecology and nesting patterns of chimpanzees (Pan troglodytes) in Issa, Ugalla, western Tanzania. Doctoral dissertation, University of Southern California, USA

Hernandez-Aguilar RA (2009) Chimpanzee nest distribution and site reuse in a dry habitat: implications for early hominin ranging. J Hum Evol 57:350-364. https://doi.org/10.1016/j.jhevo 1.2009.03.007

Hoppe-Dominik B (1984) Etude du spectre des proies de la panthère, Panthera pardus, dans le Parc National de Taï en Côte d'Ivoire. Mammalia 48:477-487

Isbell LA (1990) Sudden short-term increase in mortality of vervet monkeys (Cercopithecus aethiops) due to leopard predation in Amboseli National Park, Kenya. Am J Primatol 21:41-52

Isbell LA (1991) Contest and scramble competition: patterns of female aggression and ranging behavior among primates. Behav Ecol 2:143-155

Isbell LA (1994) Predation on primates: ecological patterns and evolutionary consequences. Evol Anthropol 3:61-71

Isbell LA (2006) Snakes as agents of evolutionary change in primate brains. J Hum Evol 51:1-35. https://doi.org/10.1016/j.jhevo 1.2005.12.012

Isbell LA, Enstam KL (2002) Predator (in)sensitive foraging in sympatric female vervets (Cercopithecus aethiops) and patas monkeys (Erythrocebus patas): A test of ecological models of group dispersion. In: Miller LE (ed) Eat or be Eaten. Cambridge University Press, Cambridge, pp 155-168

Iwamoto T, Mori A, Kawai M, Bekele A (1996) Anti-predator behavior of gelada baboons. Primates 37:389-397

Jaffe KE, Isbell LA (2010) Changes in ranging and agonistic behavior of vervet monkeys (Cercopithecus aethiops) after predatorinduced group fusion. Am J Primatol 72:634-644. https://doi. org/10.1002/ajp.20821

Janson CH, Goldsmith ML (1995) Predicting group size in primates: foraging costs and predation risks. Behav Ecol 6:326-336

Josephs N, Bonnell T, Dostie M, Barrett L, Henzi SP (2016) Working the crowd: sociable vervets benefit by reducing exposure to risk. Behav Ecol 27:988-994. https://doi.org/10.1093/beheco/arw003

Majolo B, de Bortoli Vizioli A, Schino G (2008) Costs and benefits of group living in primates: group size effects on behaviour and demography. Anim Behav 76:1235-1247. https://doi. org/10.1016/j.anbehav.2008.06.008
McLester E, Stewart FA, Piel AK (2016) Observation of an encounter between African wild dogs (Lycaon pictus) and a chimpanzee (Pan troglodytes schweinfurthii) in the Issa Valley, Tanzania. Afr Primates 11:27-36

Mitani JC, Sanders WJ, Lwanga SJ, Windfelder TL (2001) Predatory behavior of crowned hawk-eagles (Stephanoaetus coronatus) in Kibale National Park, Uganda. Behav Ecol Sociobiol 49:187-195

Morse DH (1977) Feeding behavior and predator avoidance in heterospecific groups. Bioscience 27:332-339

Nakazawa N, Hanamura S, Inoue E, Nakatsukasa M, Nakamura M (2013) A leopard ate a chimpanzee: first evidence from East Africa. J Hum Evol 65:334-337. https://doi.org/10.1016/j.jhevo 1.2013.04.003

Piel AK, Lenoel A, Johnson C, Stewart FA (2015) Deterring poaching in western Tanzania: the presence of wildlife researchers. Glob Ecol Conserv 3:188-199. https://doi.org/10.1016/j.gecco.2014.11.014

Piel AK, Strampelli P, Greathead E, Hernandez-Aguilar RA, Moore J, Stewart FA (2017) The diet of open-habitat chimpanzees (Pan troglodytes schweinfurthii) in the Issa valley, western Tanzania. J Hum Evol 112:57-69. https://doi.org/10.1016/j.jhevo 1.2017.08.016

Quinn JL, Cresswell W (2006) Testing domains of danger in the selfish herd: sparrowhawks target widely spaced redshanks in flocks. Proc R Soc B Biol Sci 273:2521-2526. https://doi.org/10.1098/ rspb.2006.3612

Ramirez-Amaya S, McLester E, Stewart FA, Piel AK (2016) Savanna chimpanzees (Pan troglodytes schweinfurthii) consume and share blue duiker (Philantomba monticola) meat in the Issa Valley, Ugalla, western Tanzania. Pan Afr News 22:1-6

Ray J, Sunquist M (2001) Trophic relations in a community of African rainforest carnivores. Oecologia 127:395-408. https://doi. org/10.1007/s004420000604

Russak SM (2014) Using patch focals to study unhabituated dry-habitat chimpanzees (Pan troglodytes schweinfurthii) and sympatric fauna at Issa, Ugalla, Tanzania. Int J Primatol 35:1202-1221. https://doi. org/10.1007/s10764-014-9803-3

Sarmiento EE, Stiner EO, Brooks EGE (2001) Red-tail monkey Cercopithecus ascanius distinguishing characters and distribution. Afr Primates 5:18-24

Skorupa JP (1989) Crowned eagles Strephanoaetus coronatus in rainforest: observations on breeding chronology and diet at a nest in Uganda. Ibis 131:294-298

Stanford CB (1995) The influence of chimpanzee predation on group size and anti-predator behaviour in red colobus monkeys. Anim Behav 49:577-587

Stewart FA (2011) The evolution of shelter: Ecology and ethology of chimpanzee nest building. Doctoral dissertation, University of Cambridge, UK

Stewart FA, Pruetz JD (2013) Do chimpanzee nests serve an antipredatory function? Am J Primatol 75:593-604. https://doi. org/10.1002/ajp.22138

Struhsaker TT, Leakey M (1990) Prey selectivity by crowned hawkeagles on monkeys in the Kibale Forest, Uganda. Behav Ecol Sociobiol 26:435-443

Sweanor LL, Logan KA, Hornocker MG (2005) Puma responses to close approaches by researchers. Wildl Soc Bull 33:1-9

Treves A (1999) Has predation shaped the social systems of arboreal primates? Int J Primatol 20:35-67

Treves A (2000) Theory and method in studies of vigilance and aggregation. Anim Behav 60:711-722. https://doi.org/10.1006/ anbe. 2000.1528

Zuberbühler K, Jenny D (2002) Leopard predation and primate evolution. J Hum Evol 43:873-886. https://doi.org/10.1006/ jhev.2002.0605 